\title{
ON REARING THE HYDROIDS OF CERTAIN MEDUSAE, WITH AN ACCOUNT OF THE METHODS USED
}

\author{
By W. J. Rees, M.Sc. \\ Research Assistant at the Plymouth Laboratory \\ and F. S. Russell, B.A. \\ Naturalist at the Plymouth Laboratory
}

(Text-figs. I-I2)

The hydroids of the following four species of medusae have been successfully reared in the Plymouth Laboratory, Amphinema dinema (Péron \& Lesueur), Amphinema rugosum (Mayer), Rathkea octopunctata (M. Sars) and Mitrocomella brownei (Kramp). It was not known previously which were the hydroids of these medusae.

Before giving an account of this work it is necessary to clear up some confusion that has arisen as to the identity of the two species of Amphinema. Two species occur at Plymouth, $A$. dinema (Pér. \& Les.) and $A$. rugosum ${ }^{\star}$ (Mayer) (see Plymouth Marine Fauna, I93I, p. 8I).

The essential differences between the two species lie in the structure of the gonads, the form of the protuberances on the umbrella margin, and in the colour. Hartlaub (I9I4) gave a good description of A. rugosum, but unfortunately he gave this under the name $A$. dinema. He was, however, aware of the fact that there might be two species.

In $A$. dinema the gonads are simple adradial plates, the marginal protuberances are mere thickenings of the edge of the umbrella, and the colour of the two tentacle bulbs is a vivid purplish violet while the stomach is usually bright green. In $A$. rugosum the adradial gonads are folded to form a series of processes pointing inwards towards the interradii, the marginal protuberances are actually tentaculae with a central core of single endodermal cells, and the colour of the tentacular bulbst and stomach is bright yellowish brown.

Mayer (I9IO) describes the gonads of the European form of $A$. dinema as "transversely folded", but his figure of a specimen from Mousehole, Cornwall, shows them as simple. In order to make certain of the structure of these gonads transverse sections were cut. These showed the gonads as being

* MrE. T. Browne informs us that he and Dr P. L. Kramp have both agreed that this species is Stomotoca rugosa of Mayer (1900). As the generic name Amphinema is neuter the specific name should be rugosum.

$\dagger$ In Mayer's original description (I900) the tentacle bulbs are brick red, and in rgro he gives the colour of stomach and tentacle bulbs as brick red, often streaked with sooty brown. This refers to American medusae. 
simple plates on each of the eight adradial surfaces of the stomach (Fig. I). Examination of living specimens showed that the eggs tend to be distributed round the periphery of the plates, leaving a narrow central area free of eggs. In the males the plates are continuous.

r. c.

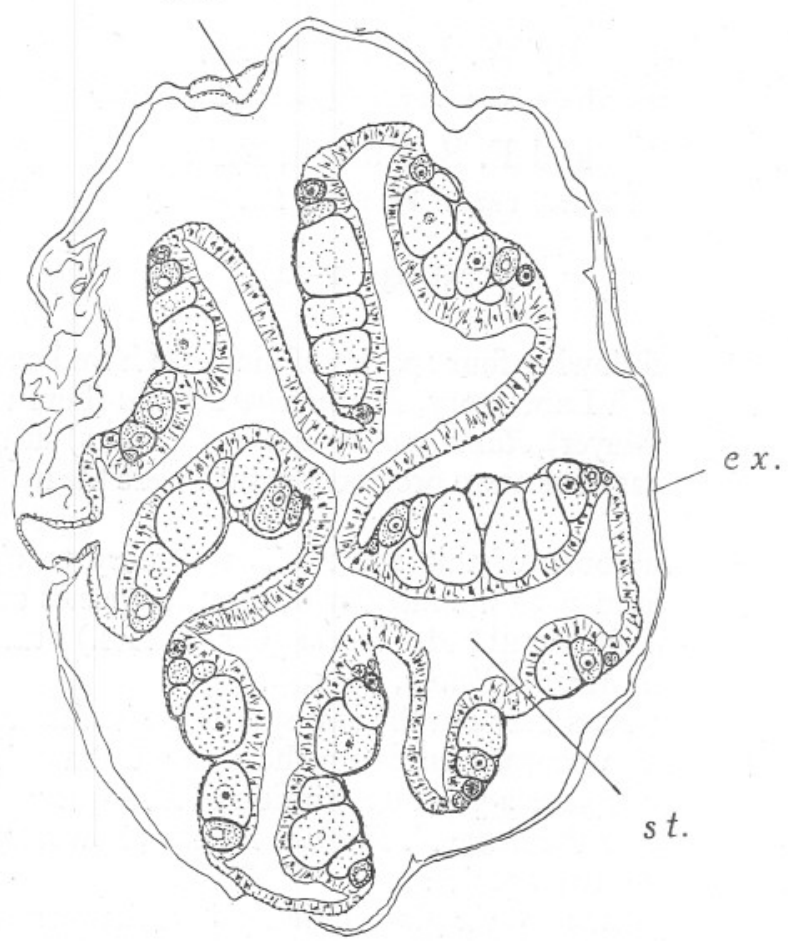

Fig. I. Transverse section through stomach region of the medusa Amphinema dinema, showing disposition of ovaries on stomach. ex. exumbrella; st. stomach cavity; r.c. radial canal. (Del. F.S.R.)

\section{Amphinema dinema (Péron \& Lesueur)}

The development of the egg to the first polyp has been described in detail by Rittenhouse (I9IO, as Stomotoca apicata) from medusae collected at Beaufort, North Carolina.

In October 1935 ripe Amphinema dinema medusae collected off Plymouth were isolated in a finger bowl and fertilized eggs obtained. Development proceeded as described by Rittenhouse. Medusae placed in bowls at 9.30 a.m. on October Io had shed no eggs at 5.Io p.m., but at 9 a.m. the next morning eggs were present, mostly in the first cleavage stage. The eggs were opaque and $0.15 \mathrm{~mm}$. in diameter. In the later stages of segmentation the blastomeres often became irregularly disposed. The planulae, which were $0.25 \mathrm{~mm}$. long 
<smiles>CC1CCCCC1</smiles>

$a$
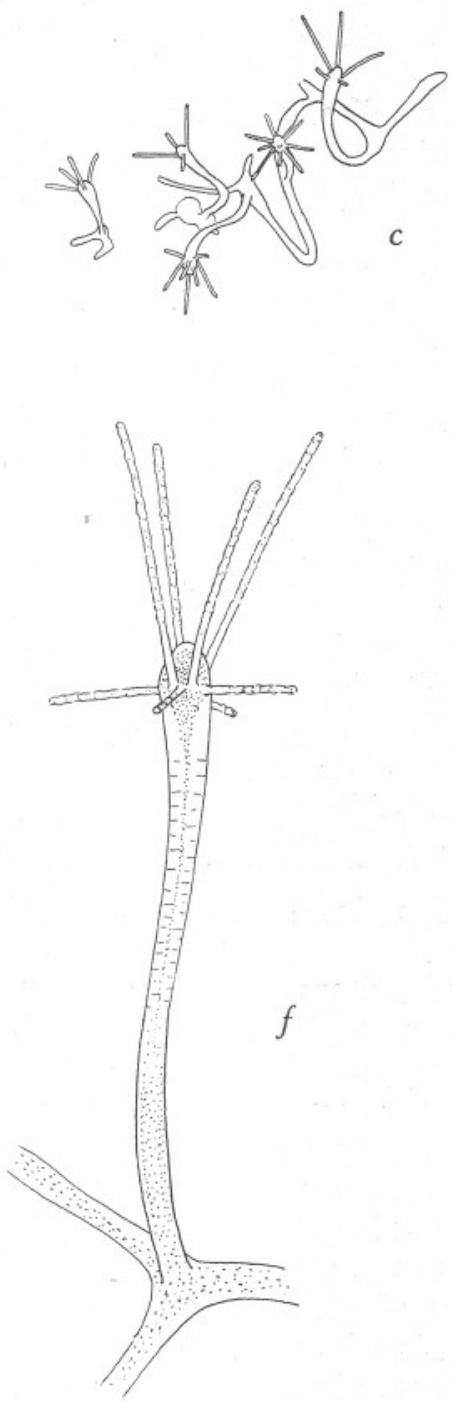

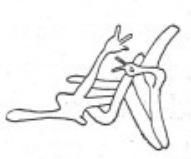

b<smiles>C=CCCCO</smiles>
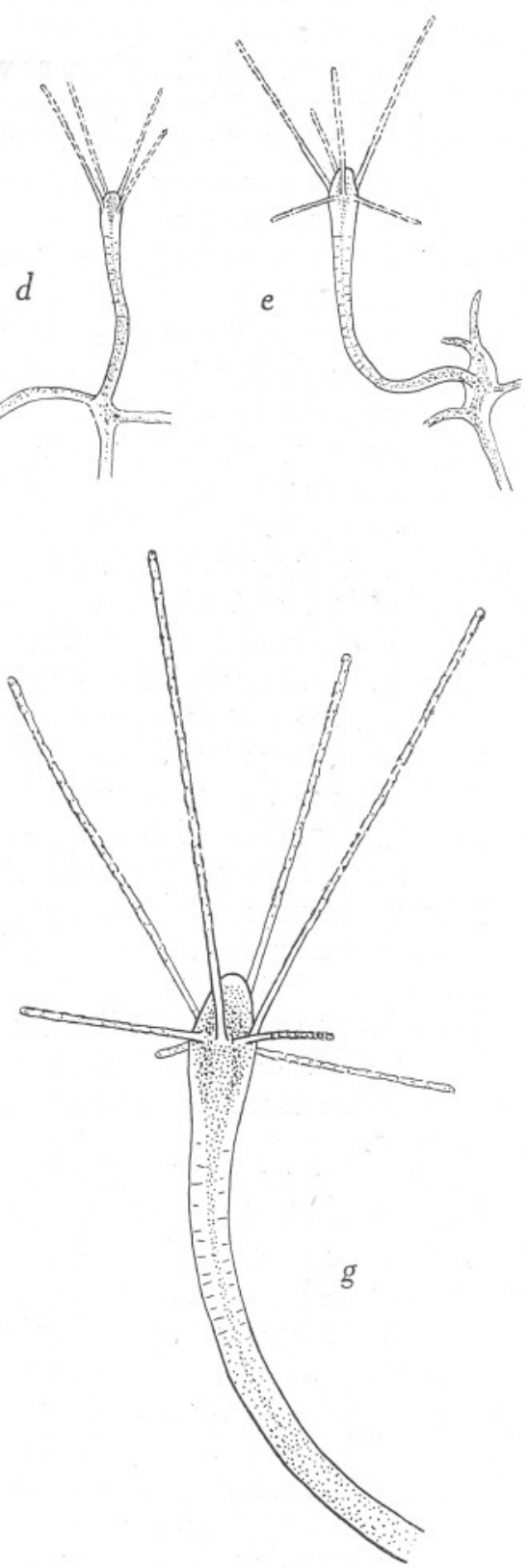

Fig. 2. $a-f$, stages in development of hydroids reared from Amphinema dinema. a, 9.45 a.m., I4. X. $35 ; b, 9.30$ a.m., I5. X. $35 ; c$, II.I5 a.m., I6. X. 35; $g$, Polyp of Perigonimus serpens dredged from Eddystone Grounds, 3. ii. 36. (Del. F.S.R.) 
and $0.09 \mathrm{~mm}$. wide, at first came to the surface but later settled to the bottom. The settled planula was pink and appeared to fix along its whole length, forming a stolon from the centre of which the first polyp developed (Fig. 2a). The development of the polyps was rapid, and 2 days after the settling of the planulae some had six tentacles. They were now a pale pink in colour. The young hydroids were kept until many had eight tentacles (Figs. $2 b-f$ ).

On February 3 I 936 a colony of Perigonimus serpens was dredged from the Eddystone grounds attached to the base of a stem of Eunicella verrucosa. Except for their brilliant reddish orange coloration these polyps were identical in appearance with those reared from Amphinema dinema (Fig. $2 g$ ).

On March 20 and subsequent days a few medusae were liberated from this Perigonimus serpens colony. The young medusae (Fig. 3) were $0.6-0.7 \mathrm{~mm}$. in height, the umbrella was slightly higher than wide, and there were scattered nematocysts on the exumbrella. There was no apical projection. The velum was broad. The stomach was cylindrical and about one-third the length of the subumbrella cavity. The mouth was simple. The four radial canals were fairly broad. There were two opposite perradial tentacles with large basal bulbs, two small opposite perradial marginal protuberances, and four indications of interradial protuberances. The colour of the tentacle bulbs and stomach was reddish orange, and in some there was a faint green tinge in the stomach.

The medusae were kept alive for several days but soon developed abnormally or

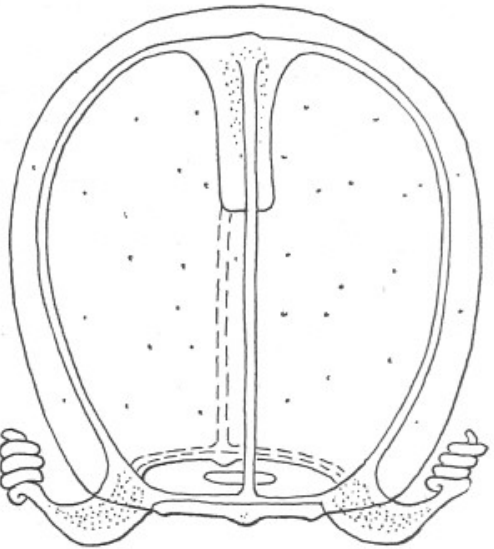

Fig. 3. Newly liberated medusa of Amphinema dinema, $0.7 \mathrm{~mm}$. high, Plymouth, 21. iii. 36. (Del. F.S.R.) turned inside out and died. The stomach in all specimens, however, turned a vivid green.

On October I4 1936 a further supply of mature Amphinema dinema medusae was obtained off Plymouth. After 3 days these medusae had shed a large number of opaque eggs $0.14-0.155 \mathrm{~mm}$. in diameter. These were separated into three finger bowls. By October 2I planulae had developed in all three bowls; they were yellowish white or slightly pinkish in colour. They were ciliated all over, and the anterior end was blunter and thicker than the more pointed posterior end. They were $0.25 \mathrm{~mm}$. in length and $0.085-0.09 \mathrm{~mm}$. in width. The planulae attached themselves to the glass along their whole length to form short stolons from the centre of which the young polyps developed. New stolons also grew out from their sides so that by October 24 when the first polyps had developed the presence of three radiating stolons was a characteristic feature (Fig. $2 f$ ). The hydranths were club-shaped with four to six tentacles. Both polyp and hydrocaulus were somewhat brownish in 
colour. Two days later a piece of glass carrying the young hydroids was cut from the bowl and hung in a beaker in which the water was kept agitated. The polyps now fed on small copepods and nauplii, and their stolons soon began to ramify over the glass and send up secondary polyps. These gradually became pale orange brown in colour.

Polyps reared in the other two finger bowls were not removed to beakers until October 30, but although fed and kept under the same conditions as the first colony transferred they did not thrive. They lived for many months (until March 1937) but never appeared healthy, a condition possibly brought about by starvation in the finger bowls at a critical stage of their development.

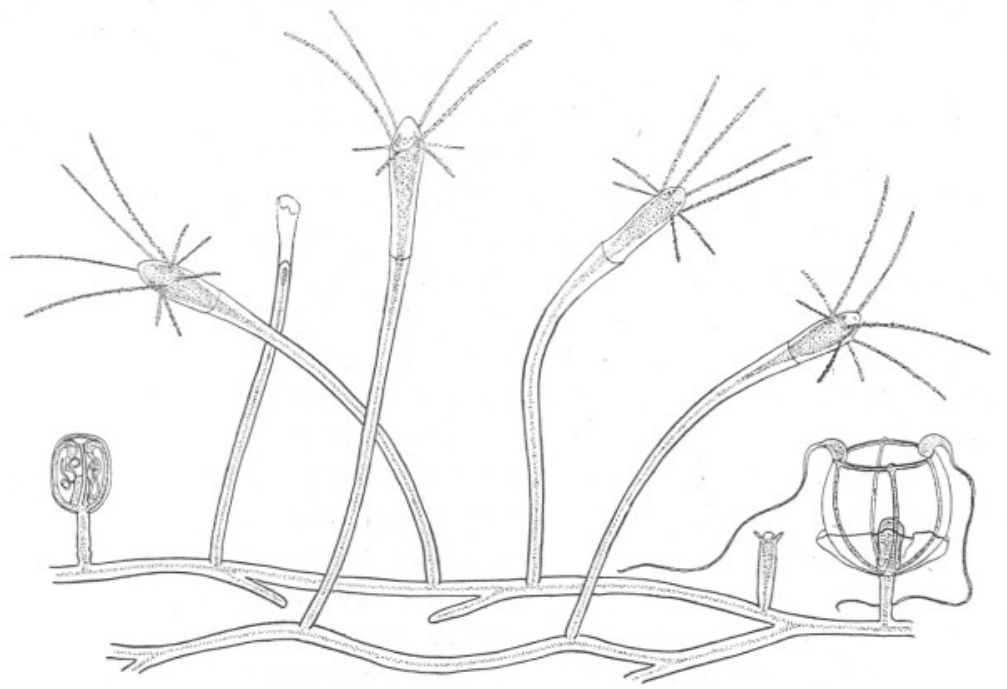

Fig. 4. Colony of hydroid with medusa buds reared from the medusa Amphinema dinema in the laboratory, Plymouth, 2I. xii. 37. (Del. W.J.R.)

The initial polyps when fully grown (Fig. 4) were club-shaped and had eight filiform tentacles in a single whorl round the bluntly conical hypostome. The secondarily developed polyps were similar in form, each with a whorl of six to ten, usually eight to ten, alternately elevated and depressed tentacles. There was no sharp demarcation between the hydranth and the hydrocaulus. The limits and relative thickness of the perisarc of the hydrocaulus were clearly shown by staining with chlorazol black (see Cannon, I937). In young polyps the perisarc is very difficult to see; in older specimens it is thin, non-annulated and transparent and adheres closely to the coenosarc, becoming horn coloured in the oldest parts. ${ }^{\star}$ At its point of origin from the stolon it may occasionally

* On November I2 1907, Mr E. T. Browne recorded a specimen dredged from the Duke Rock on a Laminaria root (see Plymouth Marine Fauna, I931, p. 67). His manuscript notes say that some of the polyps were "clothed with particles of fine mud, etc." From the description in his notes there can be no doubt that he had the $A$. dinema hydroid. 
be slightly wrinkled. At its upper end it becomes very thin and membranous and does not form a true cup round the base of the hydranth. In well-grown specimens, however, it may enlarge to form a simple narrow funnel which is very elastic and bends with the hydranth, fitting it like a glove. The membranous portion of the perisarc is almost invisible in living specimens, but when the polyp dies down it can be clearly seen before it eventually breaks off. The upper limits of the perisarc could however sometimes be seen in starved polyps in which the neck of the hydranth had shrunk and become narrower than the region below to which the surrounding perisarc was adhering. The figure given by Hincks (1868, pl. I6, fig. 3) has this appearance.

As the colony grew older the creeping stolons anastomosed to form an open network; the colour of the polyps deepened to a bright reddish orange, the tip of the proboscis remaining white. By the end of November the colony was very large and healthy and covered all the available surface of the glass. The hydrocaulus occasionally branched once.

On December I4 medusa buds were developing, rising from the creeping stolons on short stalks (Fig. 4). The stalk was somewhat wrinkled and was never longer than the fully grown medusa bud. Buds nearly ready for liberation were $0.30-0.33 \mathrm{~mm}$. long and $0.20-0.23 \mathrm{~mm}$. wide, with stalks $0.20-0.22 \mathrm{~mm}$. in length and $0.05 \mathrm{~mm}$. in width. When the bud reached its full size the thin enclosing membrane ruptured and its remains could be seen attached to the top of the stalk. The two long tentacles were uncoiled in the water, and after many pulsations the bell broke away from the peduncle. The newly liberated medusa was identical in every respect with that described above from Perigonimus serpens, its height being also $0.7 \mathrm{~mm}$.

On March 4 and May 26 I937 two colonies of $P$. serpens attached to pieces of dead Eunicella were dredged off the Mewstone. These colonies and the living colony reared from Amphinema dinema were compared side by side. In form and colour they appeared identical. The following measurements (in $\mathrm{mm}$.) made on one of the colonies revealed no appreciable differences in dimensions.

Height of polyp

Diameter of hydranth

Diameter of hydrocaulus

Length of longer tentacles expanded

Length of shorter tentacles

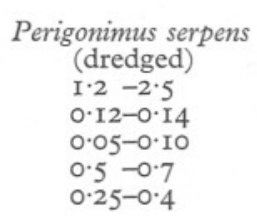

Amphinema dinema (reared from medusa)

$\mathrm{I} \cdot 5-2 \cdot 3$

$0 \cdot$ II -0.15

$0.05-0.08$

$0.7-\mathrm{I} \cdot \mathrm{I}$

$0.35-0.5$

In both colonies the number of tentacles on a single hydranth was rarely less than eight or more than ten. One of these colonies produced medusae identical with those described above. There can therefore be no doubt that the hydroid reared from the medusa Amphinema dinema (Pér. \& Les.) is identical with Perigonimus serpens Allman. 
The perisarc at the top of the hydrocaulus reached a diameter of as much as $0.2 \mathrm{~mm}$. in old polyps, but the enlargement towards the upper end was more gradual and less demarcated than in the hydroid of Amphinema dinema and the upper end was not membranous. The perisarc always ended abruptly and the hydranth was not at all retractile. That part of the stem covered by perisarc was 2.0-3.0 $\mathrm{mm}$. long.

The hydranths were large and club-shaped, $0.5-0.75 \mathrm{~mm}$. in length, and had eight to twelve filiform tentacles, alternately elevated and depressed, around a conical hypostome. The tip of the hypostome was opaque white, the rest of the hydranth being bright reddish orange. The nematocysts were scattered along the tentacles as in the $A$. dinema hydroid.

The medusa buds were borne on short stalks $0.15-0.22 \mathrm{~mm}$. long both on the stolons and on the hydrocauli. These stalks were wrinkled or annulated. The majority of the medusa buds arose from the stolon, and of the few that arose from the hydrocauli there were never more than two on each hydrocaulus. The largest buds were 0.35 by $0.25 \mathrm{~mm}$. The medusa buds were covered by a thin perisarc which ruptured to liberate the medusae.

The newly liberated medusae were $0.42-0.65 \mathrm{~mm}$. in height (Fig. 6). The umbrella was as wide as it was high; there were scattered nematocysts on the exumbrella. There was always a small apical projection and usually the remains of an apical canal. The velum was broad. The stomach was large and cylindrical and about half the length of the subumbrella cavity; it had a rather broad base. The mouth was simple. The four radial

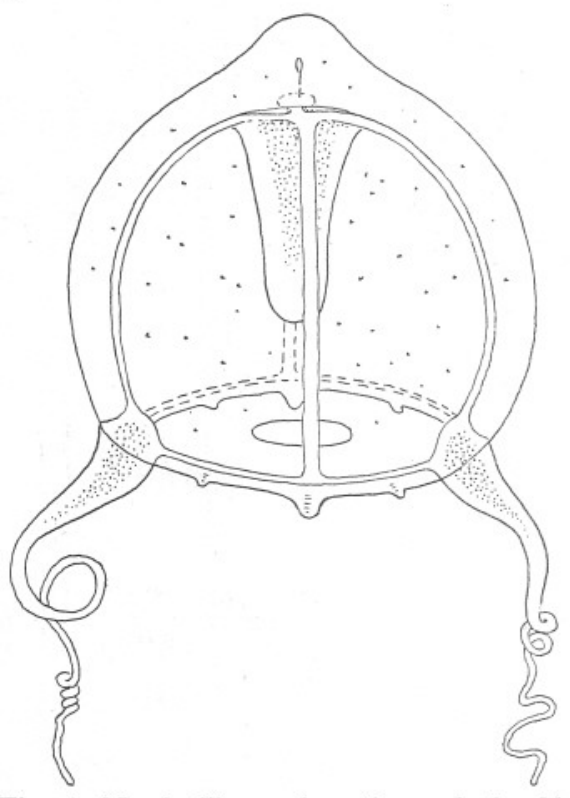

Fig. 6. Newly liberated medusa of Amphinema rugosum, $0.55 \mathrm{~mm}$. high, Plymouth, 26. vi. 37. (Del. F.S.R.)

canals were fairly broad. There were two opposite perradial tentacles with large basal bulbs; two small opposite perradial young marginal tentaculae and four interradial tentaculae developing, in all of which an endodermal core was present. The colour of the tentacle bulbs was reddish orange, with a faint tinge of yellow along the under side; the colour of the stomach was bright ochreish yellow with traces of the tentacular reddish orange pigment at its base.

This medusa thus differed from the first stage of A. dinema in the following points; it possessed an apical projection; the perradial and interradial marginal protuberances were much more pronounced and obviously developing tentaculae; the colour of the stomach was quite distinctive-typical of that of the 
adult $A$. rugosum. Although kept alive for several days there was no sign of green coloration on the stomach. There can be little doubt that these were A. rugosum.

The characteristics of the hydroid described above were confirmed from a microscopical preparation kindly sent by $\mathrm{Mr}$ E. T. Browne of a specimen that he obtained on October 8 I897.* His manuscript notes read as follows:

Perigonimus ?serpens.

On a crab-pot rope. About 3 miles south of Mewstone. A small Perigonimus which corresponds somewhat to the description given by Allman of $P$. serpens is very abundant upon the rope. It has gonophores upon the stolon and some free medusae were taken in the jar in which the colony was placed. The stolons (?) are often turned up and form stems upon which the gonophores are attached.

I898. Microscopical preparations of the colonies show that this hydroid does not correspond to the description of the $P$. serpens Allman. But it is more like $P$. serpens than any of the other species. There is no cup-like expansion of the perisarc at the base of the hydranth. The hydranths correspond to the figure given by Allman.

Allman only figures the gonophores (medusae) upon the stolon. In the Plymouth specimens the gonophores are upon the creeping stolons and also upon the stems. The stems which bear the gonophores usually terminate in a large club-shaped knob. As a rule the fully developed hydranth has no gonophores attached to it, but occasionally an individual is seen with a gonophore on the stalk. The stems which bear gonophores also have hydranths, one or two, on short stalks and small in size.

The stalk of the gonophore is slightly wrinkled as figured by Allman. The perisarc of the hydranth upon the stem is annulated like the gonophores.

Hydranths with about ten to twelve tentacles.

A re-examination of this preparation has revealed no important differences from the hydroid of Amphinema rugosum described above. The dimensions of Mr Browne's specimen agree with ours and there can be little doubt that they are the same species. The essential differences between the two species are thus as follows:

Hydroid:

Base of hydrocaulus

Upper end of hydrocaulus

Height of hydranth

Diameter of hydrocaulus

Medusa buds borne on

Medusa on liberation:

Apical projection

Colour of stomach

\section{Amphinema dinema}

Not annulated

A membranous dilatation

I. $5-2 \cdot 3 \mathrm{~mm}$.

$0.05-0.10 \mathrm{~mm}$.

Stolon

Absent

Reddish orange becoming green
Amphinema rugosum

Annulated

Not membranous

$2.5-3.5 \mathrm{~mm}$.

$0.10-0.20 \mathrm{~mm}$.

Stolon and hydrocaulus

Present

Ochreish yellow

Perigonimus serpens was originally described by Allman (1863) from a colony found growing on the basal portion of Plumularia setacea in Torbay. From his description of the medusa liberated from the hydroid it is evident that Allman

* See Plymouth Marine Fauna, I931, p. 67, recorded as Perigonimus serpens. 
had the hydroid of Amphinema dinema. The medusa had no apical process and the marginal protuberances were not indicated as being so well developed as they are in the newly liberated medusa of $A$. rugosum. There were also no annulations on the hydrocaulus of the hydroid. The hydroid Perigonimus serpens has been recorded as follows: Torbay (Allman, I872), Ilfracombe and Filey Brigg (Hincks, I868), Plymouth (Marine Biological Association, I93I); North Sea (Winther, I880; Hartlaub, I897); Mediterranean (Richiardi, I880; Motz-Kossowska, I905, on Cellaria fistulosa and Gorgonia sp.). In view of the similarity between the hydroids of Amphinema dinema and A. rugosum it is, however, impossible to say for certain to which species these records refer.

Allman (I863) referred his Perigonimus serpens to the genus Perigonimus Sars 1846 of which $P$. muscoides is the genotype. Stechow (I923) has suggested restricting the genus Perigonimus to P. muscoides and its nearest related forms and excluded provisionally all other so-called "Perigonimus" spp., which lack polysiphony and liberate medusae with two tentacles, on the grounds that they are not cogeneric with the genotype. For the moment he suggests placing all these species in the medusa genus Leuckartiara Hartlaub, I9I4, presumably (although he does not say so) with Perigonimus repens Wright, I857, as the genotype. Whether this step is justifiable with regard to all so-called "Perigonimus" spp. is uncertain because the adult stage of the gonosome of P. muscoides is not yet known and with few exceptions the medusae of all other "Perigonimus" spp. are also unknown. The medusa of P. muscoides is known however to be liberated with four tentacles already developed; it cannot therefore be cogeneric with the P. serpens-like hydroids of Amphinema dinema and A. rugosum in which the adult medusa never has more than two tentacles. For this last reason also Amphinema cannot be included in the genus Leuckartiara. It is therefore proposed to place these two hydroids provisionally in the medusa genus Amphinema $a^{\star}$ Haeckel, I879. The specific name "dinema Péron \& Lesueur, I809" has priority over Allman's Perigonimus serpens which he used

* Haeckel (1879) established the genus Amphinema for " Tiarids with two opposite perradial tentacles. No peduncle. No mesenteries. Stomach with broad base. Gonads four pairs of adradial longitudinal swellings with cross-folds or four perradial pinnate plates (gefiederte Blätter)." Hartlaub (I9I4) redefined the genus as having "Gonads forming adradial series of pockets". The genus should now be redefined as "Pandeids with two opposite perradial tentacles. No peduncle. No mesenteries. Stomach with broad base and not extending beyond umbrella margin. Gonads four pairs of adradial simple or folded swellings. Hydroid "Perigonimus serpens'-like."

Some authors have regarded Amphinema as synonymous with Stomotoca Agassiz, I862, the species of which have a peduncle. Whether this should be regarded as a specific character must be a matter of opinion, but until the hydroids of the species of Stomotoca are known it is advisable to keep the two genera separate. If, however, the hydroid should be found to resemble those of the Amphinema species here described the name Amphinema may have to give way to Stomotoca. A full discussion of the synonymy of the group seems premature until more is known about the hydroids.

Haeckel called his genotype Amphinema titania. This was the specific name given by Gosse (I853, p. $387, \mathrm{pl}$. XXVI, figs. 7-9) to what was presumably $A$. dinema. Unfortunately, Haeckel has described the medusa as having folded gonads and his figures (pl. IV, figs. 8 and 9) resemble much more closely $A$. rugosum. There seems little doubt that he has confused the two species. In our new definition of the genus Amphinema we regard A. dinema (Pér. \& Les.) as the genotype. 
to describe both the hydroid and young medusa. $P$. serpens Allman thus becomes synonymous with Amphinema dinema (Pér. \& Les.), while the other hydroid here described for certain for the first time* becomes $A$. rugosum (Mayer).

While discussing Perigonimus spp. it seems opportune to bring forward the question of the identity of a species described by Hincks (1877) as P.? nutans. From the description and figure of this hydroid it seems very possible that it was a young polyp of the $P$. serpens type. There will never be any possibility of the certain identity of the species, and as it possesses no annulations at the base of the hydrocaulus we propose that the name $P$.? nutans Hincks should be sunk in the synonymy of Amphinema dinema.

\section{Rathkea octopunctata (M. Sars)}

A number of mature medusae of Rathkea octopunctata were caught off Plymouth in April I937. The first successful fertilizations were obtained on April I4. The eggs were opaque white, and $0.14 \mathrm{~mm}$. in diameter. Planulae had developed on the I8th; these were ciliated and pear-shaped, being 0.15 by $0.1 \mathrm{~mm}$. These planulae, some of which were kept in the dark and some in the light, failed to settle on the glass bottoms of the bowls.

Another successful fertilization was made on April 20, and 3 days later planulae had developed from eggs $0.14 \mathrm{~mm}$. in diameter. These were distinctly larger and more active than those previously mentioned; they were $0.20-$ $0.24 \mathrm{~mm}$. in length and $0.08-0.09 \mathrm{~mm}$. in width. In shape they were somewhat cylindrical and bluntly rounded at both ends, the anterior end being usually slightly the wider. Some planulae about to settle had a slight depression at the posterior end.

A small piece of skeleton from the basal stem of Eunicella verrucosa (which had been previously boiled) was placed in a bowl with planulae in it on May I. The next day at 3.30 p.m. about six planulae had settled on the Eunicella and others were in the act of settling. They attached by the anterior end leaving the posterior end free. On May 5 tentacles were developing at the free end of the larva, and on the next day a few had three or four very short tentacles. The maximum height of the polyps at this stage, including the tentacles, was $0.20 \mathrm{~mm}$.

By May 7 the tentacles had grown in size and were capable of considerable extension, becoming very delicate and thread-like when fully extended as in Trichydra. They were arranged in a single whorl of three or four around a slightly opaque white proboscis. On the same date a single polyp with three

\footnotetext{
* Brooks (1883) described from Beaufort, North Carolina, a hydroid from which he reared "Amphinema apicatum (Haeckel)". The synonyms he gave are those of the American form of A. dinema. Mayer (19ro) has, however, regarded Brooks' hydroid as being that of A. rugosum. Brooks' description of the young medusa fits closely to $A$. dinema; there was no apical projection in the first stage and only marginal enlargements rather than tentaculae are mentioned. His description of the hydroid differs from Perigonimus serpens in that the medusa buds arose from the stems; in fact Brooks likened the hydroid to P. minutus.
} 
tentacles was found attached to the glass bottom of another bowl. While searching in this bowl it was suddenly found that there were great numbers of extremely fine tentacular processes issuing from two small masses of detrital matter stuck to the glass. These proved to belong to polyps which must have developed from planulae which had found here a peculiarly suitable settling ground. Other bowls, which had been set on one side since there were no signs of settled planulae on the glass, were then examined, and several more very small masses of detritus were found each with large numbers of fine tentacles issuing from them. In these, of course, the developing planulae would have been completely buried and invisible. These polyps were exactly the same in every respect to those which had developed on the Eunicella from planulae which were seen to settle. There can thus be no possibility that the polyps or planulae from which they arose had been carried into the bowl with the outside

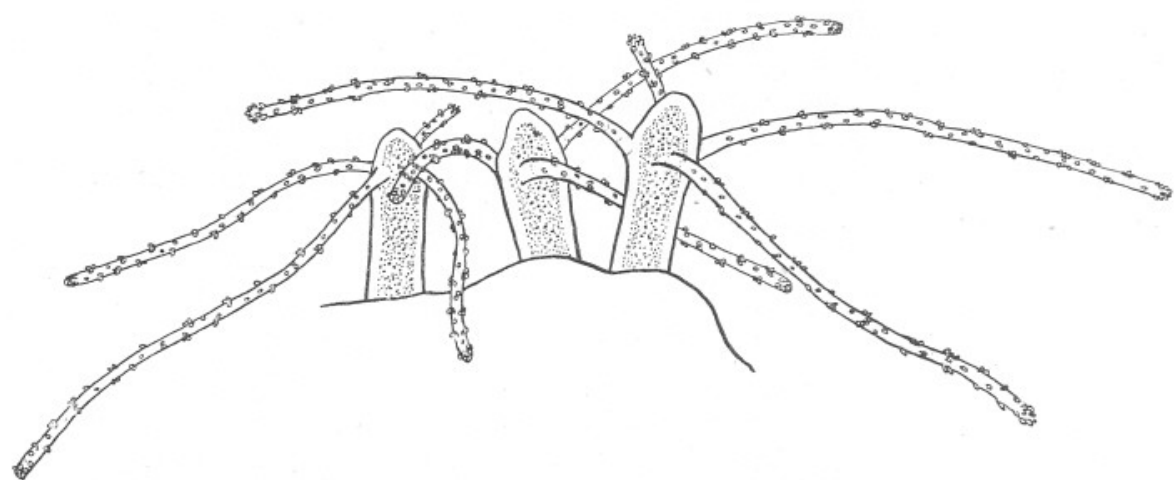

Fig. 7. Hydroids reared from the medusa Rathkea octopunctata attached to a piece of stem of Eunicella; tentacles partially contracted, Plymouth, I5. v. 37. (Del. W.J.R.)

sea water used. Rather it was that the small amount of detrital matter which is always present in unfiltered sea water had collected together on the bottom to form small flocculent masses of just the right texture for the Rathkea planulae to settle in, and these had cemented the detritus to the glass. Measurements of one of these polyps on May 7 showed the hydranth projecting out of the detritus only to a length of $0.1 \mathrm{~mm}$., the extended tentacles measuring up to $c a .0 .4 \mathrm{~mm}$. in length.

On May Io a large number of polyps were found on the Eunicella which were not previously visible. The planulae of these had settled in the deep crevices and depressions of the broken ends of the stem, and it was only when their tentacles were extended that they became visible.

Polyps which had developed on the smooth sides of the Eunicella stem (Fig. 7) by May $28^{\star}$ (i.e. about I month old) still measured only about $0.15-$ $0.20 \mathrm{~mm}$. in height from the substratum to the top of the hypostome, while

* After 5 months (28. ix. 37) some polyps are still alive and show no further development. 
those in the detrital masses were extended to a length of $0.12-0.27 \mathrm{~mm}$. There were usually four or five tentacles, and occasionally six, in a single whorl. The tentacles were capable of great extension, to a length of I.3 mm., and when

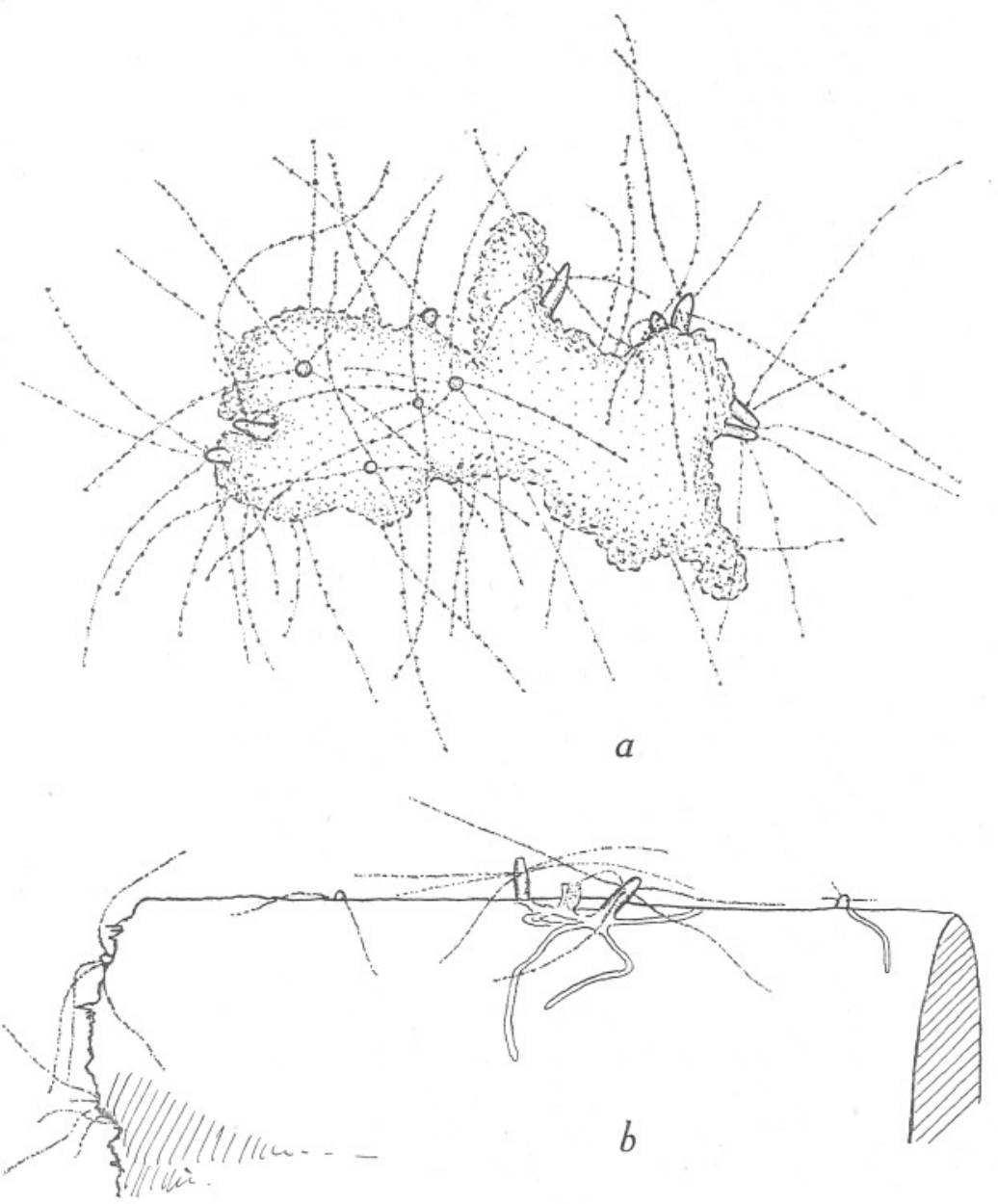

Fig. 8. a, colony of hydroids reared from the medusa Rathkea octopunctata whose planulae settled in a small mass of detritus, Plymouth, 28. v. 37. (Del. W.J.R.) $b$, hydroids reared from Rathkea octopunctata, Plymouth, 28. v. 37, drawn to show stolons creeping over stem of Eunicella and typical attitude of the tentacles of the polyps. On the right is a developing secondary polyp. Between the two centre polyps is an empty perisarc tube. Tentacles are also seen on the left side issuing from polyps growing in clefts at the broken end of the stem. (Del. F.S.R.)

fully extended were extremely delicate and thread-like. If the water was disturbed while the tentacles were fully expanded they were thrown into loose uncontrolled curves. When seriously disturbed, however, they could contract so that they reached only a short distance above the end of the hypostome. 
The tentacles when extended are held out at right-angles so that they lie absolutely flat along the surface of the substratum (Fig. 86 ). In polyps in the detritus which were perforce projecting out horizontally, those tentacles on the lower side were pressed firmly against the glass. A detrital mass left under the microscope some time to allow the polyps to expand fully had a pincushion-like appearance with the tentacles projecting in all directions (Fig. $8 a$ ).

The tentacles had a core of single cylindrical endoderm cells and were covered with large numbers of nematocysts arranged in somewhat irregularly scattered groups. When the tentacles were contracted these nematocysts had the appearance of being arranged in whorls. The nematocysts measured $0.005-0.007$ by $0.002-0.003 \mathrm{~mm}$.

The hydranth body was cylindrical in form and had an elongated hypostome about $0.05-0.08 \mathrm{~mm}$. in length. This hypostome was opaque white, the rest of the polyp being colourless. The lower part of the body of the hydranth was apparently surrounded by a very thin gelatinous perisarc which was very difficult to see. Its presence was, however, indicated by detrital matter which adhered to it very easily. In fact the whole mass of detritus seemed to be held very firmly together by its adherence to the numerous perisarc tubes, and it was almost impossible to dissect a single polyp away intact.

These observations probably indicate the normal habitat of the hydroid and explain why it has not been discovered in the field. The hydroid probably lives on stones covered with a felt of minute algae and detrital matter, with only the hypostome projecting above the detrital layer and the tentacles lying flat over the surface of this layer ready to catch any minute creeping organisms. They may also live in little clefts on rough material with only their tentacles projecting.

It seems quite impossible to identify this hydroid certainly with any known described species. It appears to resemble Eudendrium pudicum of Van Beneden (I866), and also perhaps Perigonimus (?) quadritentaculatus of Hincks (I868), though it differs from the latter in that all its tentacles are of equal length. The great elongation of the tentacles and their delicate thread-like character is comparable with that of Trichydra pudica Wright. The Rathkea hydroid, however, lacks the distinct collar-like hydrothecal perisarc, and its hydranth body is not capable of the great extension so typical of Trichydra. The manner of holding the tentacles is also different.

It seems to us, therefore, wiser on the whole that any attempt to identify this hydroid should be given up and that for the time being it should bear the name of its medusa Rathkea octopunctata.

One thing is certain. The hydroid is not a Bougainvillia, and Rathkea can therefore be removed once and for all from the Margelidae and possibly placed in a family of its own. 


\section{Mitrocomella brownei (Kramp)}

At the end of April 1937 five mature specimens of M. brownei were obtained off Plymouth. While four of these were females fortunately one was a male and a successful fertilization was made. The structural details of the medusae used were as follows:

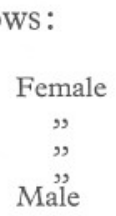

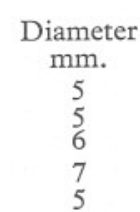

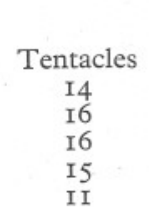

$\begin{array}{cc}\begin{array}{c}\text { Developing } \\ \text { bulbs }\end{array} & \begin{array}{c}\text { Marginal } \\ \text { vesicles }\end{array} \\ 2 & \text { II } \\ 3 & \text { IO } \\ 6 & \text { IO } \\ 5 & \text { IO } \\ 5 & \text { I I }\end{array}$

The eggs were colourless and $0.095 \mathrm{~mm}$. in diameter. They were apparently shed at night. For instance, a bowl in which the medusae had shed no eggs at 4.45 p.m. on May 7 had many gastrulae at Io a.m. the next day; this was repeated with the same results on three successive occasions. The planulae were $0.16 \mathrm{~mm}$. in length and $0.08 \mathrm{~mm}$. wide, the anterior end being slightly the thicker. The gastrulae, which were oval, remained on the bottoms of the bowls; the next day, when they were developing into planulae by proliferation of endoderm in the anterior end of the cavity, they were swimming at the surface. On the following day the fully developed planulae were once more on the bottom and within $24 \mathrm{hr}$. they appeared to be seeking for settling spots. Planulae which had developed from eggs laid between the afternoon of May 5 and morning of May 6 had fixed to the glass by the morning of the Ioth. The next day the perisarc was developing, and within 3 days the perfect hydrotheca was formed and the polyps had tentacles.

The hydroid (Figs. 9 and ro $a$ and $b$ ) is a species of Cuspidella. The hydrothecae are $0.2-0.3 \mathrm{~mm}$. in length and $0.05-0.06$ $\mathrm{mm}$. wide. The hydranth was very ex- Fig. 9. Young stages of polyps reared tensile and could extend beyond the operculum to a length of $0.5 \mathrm{~mm}$., the tentacles being $0.16 \mathrm{~mm}$. long. There were eight

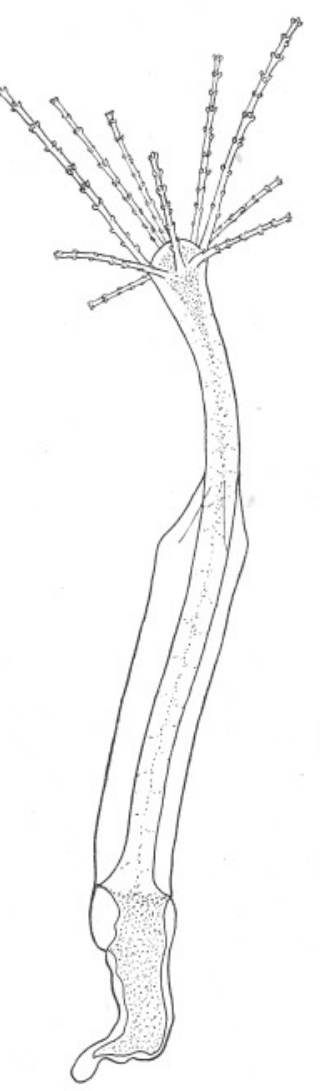

a

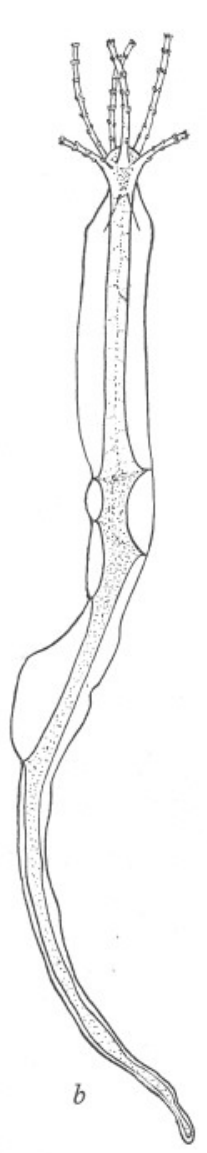
from the medusa Mitrocomella brownei, Plymouth, 18. v. 37. Width of hydrotheca: $a$, $0.06 \mathrm{~mm}$.; $b, 0.05 \mathrm{~mm}$. (Del. W.J.R.) to twelve tentacles in a single whorl, alternately elevated and depressed. 
This Cuspidella is thus about half the size of that reared from Laodicea undulata (Russell, 1936). While Cuspidella of the Laodicea size is quite common off Plymouth we have at times seen a very small species corresponding in dimensions with that reared from Mitrocomella brownei. A drawing of such a hydroid is given in Fig. II ; it differs only in having fourteen tentacles which the Mitrocomella hydroid may well have when fully developed.

The question of the actual specific name of this hydroid must remain a matter of opinion. Hincks (I868) records three species, Cuspidella costata, C. grandis, and C. humilis. Unfortunately, he gave no measurements from

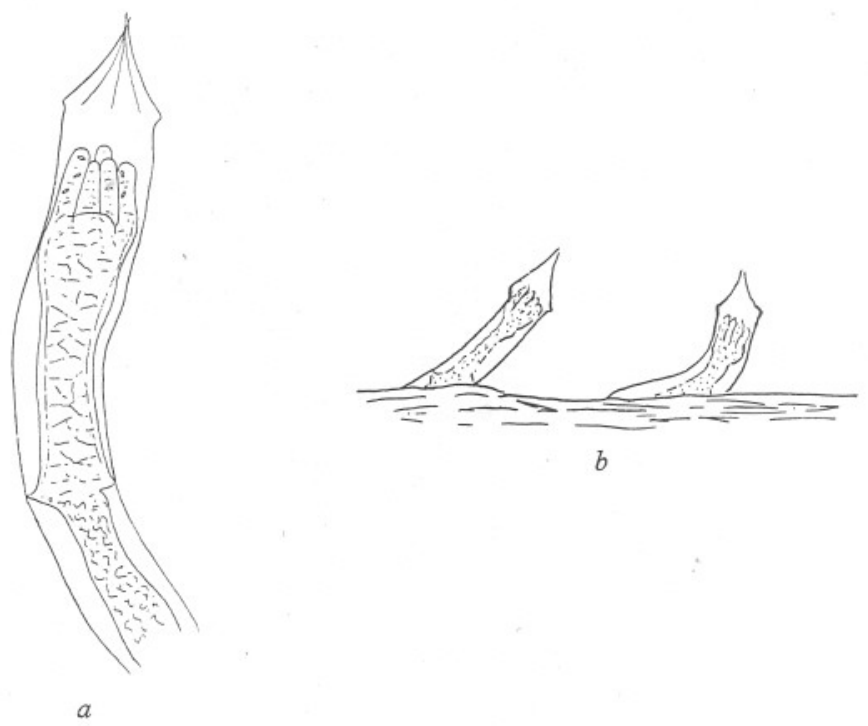

Fig. Io. a, polyp reared from Mitrocomella brownei, Plymouth, I5. v. 37. Width of hydrotheca $0.06 \mathrm{~mm}$. b, polyps reared from Mitrocomella brownei attached to stem of Eunicella. (Del. F.S.R.)

which accurately to gauge their size. Stechow (1923, p. I33) has given measurements of $C$. humilis hydrothecae as $0.065 \mathrm{~mm}$. wide. This almost agrees with the dimensions of the hydroid of Mitrocomella brownei, but in view of the fact that there may be other medusae with similar hydroids it seems to us safer to give the hydroid the name of the medusa.

While discussing Mitrocomella mention should be made of a further observation. The two genera Mitrocomella and Cosmetira are differentiated on the grounds that in the former the marginal cirri coil spirally while in the latter they do not (Kramp, I932). We have examined living specimens of Cosmetira pilosella and can state definitely that the cirri can and do coil spirally. This is especially noticeable in the younger stages, but when the medusa is preserved they are nearly all straight. It is therefore questionable whether the genus Mitrocomella should be retained, and it seems better that it should be sunk in Cosmetira. 
Browne (I9I0) kept Cosmetira and Mitrocomella distinct on the grounds that the former had only eight marginal vesicles while the latter had sixteen. This was before $M$. brownei, which normally has only eight vesicles (Kramp, I932), had been described. It thus seems that this distinction also can no longer be held valid.

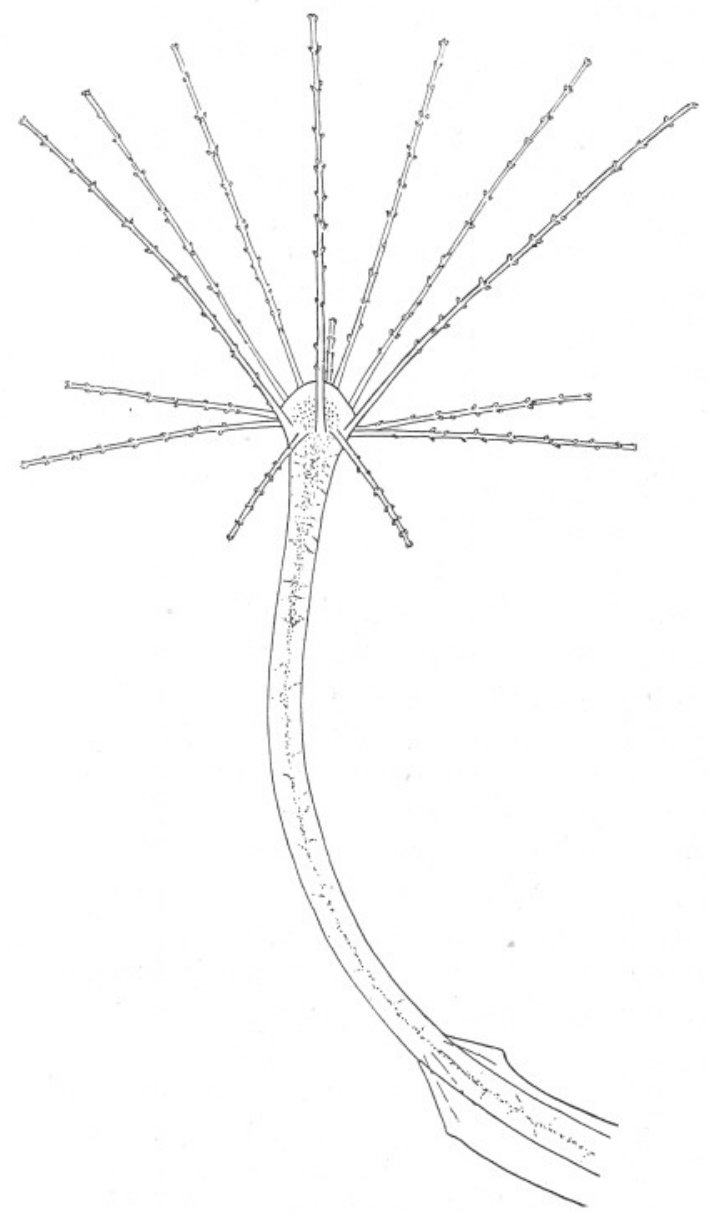

Fig. II. Fully expanded polyp of Cuspidella dredged from the Cattewater, 30. i. 36 . Width of hydrotheca $0.06 \mathrm{~mm}$. (Del. F.S.R.)

\section{THE Methods OF REARING}

During the past 50 years a number of British species of medusae have been linked to their respective hydroids. But the proportion whose hydroids remain unknown is still high. It is noticeable that most of those already linked are species whose hydroid colonies are very common, or large and easily found, and can thus often be obtained with medusa buds already developed. The 
remaining species are therefore likely to be found among the minute and less conspicuous forms. These are easily damaged while being caught and brought to the laboratory, and even if after much searching they are found the chances are slight that they will have medusa buds developed.

It was found that if small pieces of shell, stone or other objects recently dredged are left to stand for several days in bowls of outside sea water, polyps will regenerate from living stolons. In this way a number of the more minute species have been obtained. They must be kept alive until they produce medusae, and we have been able to keep colonies living for many months by the method to be described below. This method is, however, tedious, and the quickest and most certain method is to rear the hydroids from the eggs obtained from living medusae. Primary polyps have been reared from a number of species by the earlier workers, e.g. Metschnikoff, for embryological studies, but few of these were ever grown into colonies.

The method we are now using is to rear the first polyps in finger bowls from ripe medusae caught in numbers in the plankton. These are at first fed individually with small organisms such as copepod nauplii until other polyps have started growing. The glass or other object to which the small hydroids are attached is then removed and hung up by a silk thread in the apparatus described below.

The pioneer work of Browne (1898), who introduced the plunger jar system, showed that by keeping the water agitated the necessity for constant renewal of water could be obviated. Browne (1907) also described a method whereby food could be brought to a fixed hydroid colony by means of a constant current. One of the main practical disadvantages of these methods is that owing to the large volumes of water which are used much space is occupied in the laboratory and a long time is spent in searching for minute organisms.

Dr H. W. Harvey, while studying the growth of plankton diatoms, devised a method of preventing the diatoms from settling on the bottom. Its advantages were at once obvious for the rearing of hydroids and medusae, and we are much indebted to him for a method which has proved extremely successful for our research.

The essential principle is that a glass plate cut to a suitable size stands upright in a beaker so that it may be rocked backwards and forwards. Owing to the curvature at the bottom of the beaker the lower edge of the glass plate remains slightly above the bottom, leaving a clearance through which a current of water passes when the upper edge of the plate is rocked backwards and forwards. By using beakers the necessity for much space is eliminated, and we have been able to set up a battery of beakers on a small bench in which a large number of hydroids can be kept alive at the same time.

The beakers used are $5 \frac{1}{2}$ in. in height with an internal diameter of 4 in. The glass plates are about $4^{\frac{3}{4}}$ in. in length and cut just wide enough to fit the beaker without scraping its sides. The two bottom corners of a plate rest upon the incurved sides at the foot of the beaker and pivot there, while the upper edge 
of the plate has a backwards and forwards play of about I in. A glass rod, with a bent end, hooks over the top edge of the plate, the straight body of the rod projecting through the beaker spout. The free end of the glass rod is attached to a wire stretched between wooden uprights (Fig. I2 $a$ ) by a rubber tube whose end is split; the two ends of this split are fastened with a pin after the wire has been inserted between. The wooden uprights are fixed to a long horizontal wooden batten (Fig. I $2 b$ ) which is pivoted at either end in two

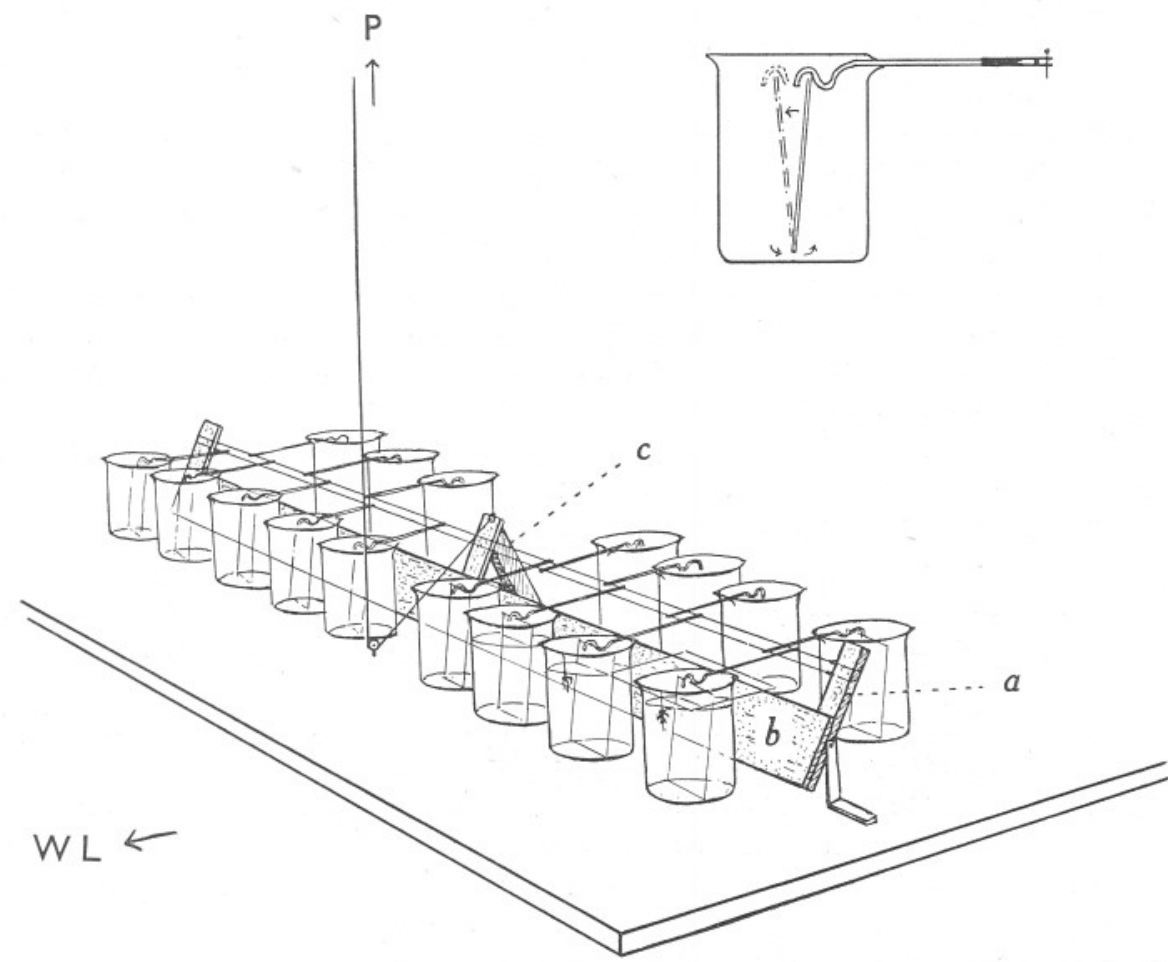

Fig. I2. Diagram showing arrangement of beakers with rocking plates for keeping hydroids. For full description see text. $a$, wooden upright; $b$, horizontal wooden batten; $c$, stopper; $P$, to plunger jar wire; $W L$, direction of window light. In the top right-hand corner is shown an enlarged drawing of a beaker and method of attachment of rubber tube to wire. (Del. F.S.R.)

angle irons screwed to the bench. A string attached to the wire which works the main plunger jar system (Fig. I2 $P$ ) of the laboratory passes under a pulley on the bench to the top of a central wooden upright on the batten. The wooden structure is set so that in the forward position of the glass plates in the beakers it is leaning slightly backwards; on the release of the tension on the plunger string it then drops backwards about an inch under its own weight against a stopper (Fig. I2 c). It is convenient to have two wires at slightly different levels on the wooden uprights to allow for inequalities in the heights of the beakers. 
The whole battery is set up on a bench about $\mathrm{I}_{4} \mathrm{ft}$. from a north window (Fig. I2 $W L$ ). Excessive plant growth is thus avoided. The colonies of hydroids are hung on silk threads just below the water surface on the side of the beaker nearest the window. An abundant supply of fine animal plankton is put at regular intervals into each beaker. Most of these animals being positively phototropic immediately collect near the surface on the lightest side of the beakers and are soon caught by the hydroid polyps. With a continuous supply of food the colonies grow very quickly and can be kept alive as long as required. Some of our colonies have remained thus over a year, the polyps dying down and regenerating at intervals.

There appears to be no necessity of changing the water, though at times it may be advantageous to do so to revive colonies that appear unhealthy, or if the accumulation of dead food organisms on the bottom becomes too great. As, however, the water can be easily changed, we have made a practice of doing so at regular intervals to ensure the best conditions possible. Up to the present most of the hydroids grown in these beakers have been somewhat sessile unbranching forms, and their growth has been quite normal and sessile. Whether the branching species will grow in their typical forms remains to be seen. This will probably depend upon an abundant food supply and on the hydroid itself hanging free from the side of the beaker. A single polyp of Bougainvillia muscus soon sent stolons on to the beaker side, and a creeping colony as described by Browne (1907) was quickly formed. In the centre of the colony, however, many of the polyps started to branch and grow upwards; these developed into quite typical growths of the $B$. fruticosa type.

In rearing primary polyps from medusae the substratum for the settling of the planulae may be of importance (see Day and Wilson, 1934). We have reared first polyps from the following species of medusae: Steenstrupia rubra, Bougainvillia britannica, Turritopsis nutricula, Rathkea octopunctata, Amphinema dinema, Laodicea undulata, Mitrocomella brownei, Phialidium hemisphericum, Phialella cymbaloides, and Octorchis gegenbauri. The planulae of all of these apparently settled without difficulty on glass except Bougainvillia britannica and Rathkea octopunctata, and possibly Octorchis. Of these the planulae of the first settled on a piece of smooth shell, but the polyps did not develop far enough to become distinctive. The settling of Rathkea planulae in detrital masses and rough hollows in the stem of Eunicella have already been mentioned. Planulae have also been obtained from Lizzia blondina; these would not settle on glass, and at the time no other substratum was offered; no doubt better success would have been obtained with a suitable substratum.

In order that the medusae may give successful results they should be brought into the laboratory in as good a condition as possible. It is best to pick the medusae out from the rest of the plankton catch on board as soon as the net comes up. Even then it was at first found that a high percentage were dead or dying at the end of the day when brought into the laboratory. On these occa- 
sions the medusae had been kept in breffits ${ }^{\star}$ filled with water. If the breffit was kept standing in the cool, with its lid on, the medusae sank to the bottom after a short time and soon became unhealthy. If placed under circulation with stramin tied over the opening and the sea-water jets playing on it, the medusae became damaged by air bubbles sticking to the umbrella surface.

It was found, however, that if the breffit were filled only to one-quarter of its capacity and then, with lid on, placed floating on its side in the circulation baths, the medusae remain in excellent condition. In this way the medusae were prevented from lying on the bottom because the breffit was continually rolling over with the motion of the ship or by the sea-water jets playing on it. Medusae picked out on board and kept in this manner were alive and active when brought into the laboratory and in such good condition as to remain alive many days in finger bowls of outside sea water until their gonads ripened.

\section{SUMMARY}

The development of the hydroid of Amphinema dinema (Péron \& Lesueur) has been followed in the laboratory until the production of young medusae and the hydroid identified as Perigonimus serpens Allman.

The hydroid of Amphinema rugosum (Mayer) is described for the first time. It is very similar to $P$. serpens but more robust.

The hydroid has been reared from Rathkea octopunctata (Sars); it is very minute and the hydranths possess a single whorl of long filiform tentacles.

A small Cuspidella hydroid was reared from Mitrocomella brownei (Kramp). Certain points in the synonymy of these species are discussed.

An account of the methods of rearing used is also given.

\section{REFERENCES}

Allman, G. J., 1863. Notes on the Hydroida. Ann. Mag. Nat. Hist., Ser. 3, Vol. xi, pp. I-I2.

— I872. A Monograph of the Gymnoblastic Hydroids. Ray Society.

BRooks, W. K., I883. Notes on the medusae of Beaufort, N.C. Part II. Fohns Hopkins Univ. Stud. Biol. Lab., Vol. II, xxxiv, pp. 465-75.

BRowne, EdWARD T., I898. On keeping medusae alive in an aquarium. Fourn. Mar. Biol. Assoc., Vol. v, pp. I76-80.

— I907. A new method for growing hydroids in small aquaria by means of a continuous current tube. Fourn. Mar. Biol. Assoc., Vol. viII, pp. 37-43.

- I910. Coelenterata. V. Medusae. National Antarct. Exped. 1901-1904. Nat. Hist., Vol. v, Zool. and Bot., pp. I-62.

Cannon, H. Graham, I937. A new biological stain for general purposes. Nature, Vol. I39, No. 3517, p. 549.

Day, J. H. \& Wilson, Douglas P., 1934. On the relation of the substratum to the metamorphosis of Scolecolepis fuliginosa (Claparède). Fourn. Mar. Biol. Assoc., Vol. xix, pp. 655-62.

Gosse, Philip Henry, I853. A Naturalist's Rambles on the Devonshire Coast. London: John van Voorst.

* Glass jars holding $c a .2$ l. of water. 
Haeckel, ERnst, 1879. Das System der Medusen.

Hartlaub, Clemens, I897. Die Hydromedusen Helgolands. Wiss. Meeresuntersuch., N.F. Bd. II, Abt. Helgoland, Heft I, x, pp. 449-5I2.

I9I4. Nordisches Plankton. Lief. 6, XII, Craspedote Medusen. Teil I, Leif. 3 , Familie IV, Tiaridae, pp. 237-363.

Hincks, Thomas, 1868. A History of the British Hydroid Zoophytes. London: John van Voorst.

—_ 1877. Contributions to the History of the Hydroida. Ann. Mag. Nat. Hist., Ser. 4, Vol. I9, pp. 148-52.

Kramp, P. L., 1932. A revision of the medusae belonging to the family Mitrocomidae. Vidensk. Medd. Naturh. Foren. Køjb., Vol. 92, pp. 305-83.

Marine Biological Association, I93i. Plymouth Marine Fauna, 2nd Edition.

MAyer, Alfred GoldsBorough, I900. Descriptions of new and little-known medusae from the western Atlantic. Bull. Mus. Comp. Zoöl. Harvard, Vol. xxxvin, No. I, pp. I-9.

- I910. Medusae of the World. Vol. I. Hydromedusae.

Motz-Kossowska, S., I905. Contribution à la connaissance des Hydraires de la Méditerranée occidentale. I. Hydraires gymnoblastiques. Arch. Zool. Exp. Gén., Sér. 4, Tome 3, pp. 39-98.

PÉRON \& Lesueur, I809. Histoire générale et particulière de tous les animaux qui composent la famille des Méduses. Ann. Mus. Hist. Nat. Paris, Tome xiv, pp. 3I2-66.

RichIARDI, S., I880. Contribuzioni all fauna d'Italia. III. Idroidi del Mare della Toscana. Catal. Gener. Sezione Ital. Espos. Intern. Pesca Berlin, pp. I54-5.

Rittenhouse, SAmuel, I9Io. The embryology of Stomotoca apicata. Fourn. Exper.Zool., Vol. 9, No. 2, pp. 333-48.

Russell, F. S., I936. On the hydroid of Laodicea undulata (Forbes \& Goodsir). fourn. Mar. Biol. Assoc., Vol. xx, pp. 58I-8.

SARs, M., I846. Fauna Littoralis Norvegiae, I, pp. I-94. Christiania.

Stechow, E., I923. Zur Kenntnis der Hydroidenfauna des Mittelmeeres, Amerikas und anderer Gebiete. II. Teil. Zool. Fahrb. Fena (Syst.), Bd. 47, pp. 29-270.

VAn Beneden, P.-J., I866. Recherches sur la Faune Littorale de Belgique. Mém. Acad. R. Belg., Vol. xxxvi, pp. 3-207.

WINTHER, G., I880. Fortegnelse over de i Danmark og dets nordlige Bilande fundne Hydroide. Naturhist. Tidsskr., Ræk. 3, Bd. xII, pp. 223-78. 